\title{
Effects of Agelas oroides and Petrosia ficiformis crude extracts on human neuroblastoma cell survival
}

\author{
CRISTINA FERRETTI ${ }^{1 *}$, BARBARA MARENGO ${ }^{2 *}$, CHIARA DE CIUCIS $^{3}$, MARIAPAOLA NITTI $^{3}$, \\ MARIA ADELAIDE PRONZATO ${ }^{3}$, UMBERTO MARIA MARINARI ${ }^{3}$, ROBERTO PRONZATO ${ }^{1}$, \\ RENATA MANCONI $^{4}$ and CINZIA DOMENICOTTI ${ }^{3}$
}

\author{
${ }^{1}$ Department for the Study of Territory and its Resources, University of Genoa, Corso Europa 26, I-16132 Genoa; \\ ${ }^{2}$ G. Gaslini Institute, Gaslini Hospital, Largo G. Gaslini 5, I-16148 Genoa; ${ }^{3}$ Department of Experimental Medicine, \\ University of Genoa, Via Leon Battista Alberti 2, I-16132 Genoa; ${ }^{4}$ Department of Zoology and \\ Evolutionistic Genetics, University of Sassari, Via Muroni 25, I-07100 Sassari, Italy
}

Received July 28, 2006; Accepted September 20, 2006

\begin{abstract}
Among marine sessile organisms, sponges (Porifera) are the major producers of bioactive secondary metabolites that defend them against predators and competitors and are used to interfere with the pathogenesis of many human diseases. Some of these biological active metabolites are able to influence cell survival and death, modifying the activity of several enzymes involved in these cellular processes. These natural compounds show a potential anticancer activity but the mechanism of this action is largely unknown. In this study, we investigated the effects of two Mediterranean sponges, Agelas oroides and Petrosia ficiformis on the viability of human neuroblastoma cells. Upon treatment with the methanolic extract of Petrosia ficiformis, a marked cytotoxic effect was observed at any concentration or time of exposure. In contrast, a time- and dose-dependent effect was monitored for Agelas oroides that induced the development of apoptotic features and ROS production in LAN5 cells. These events were suppressed by calpeptin or zVAD and by vitamin $\mathrm{C}$ suggesting that the cell death caused by Agelas oroides was calpain- and caspasedependent and of oxidative nature. Comet assay showed that this methanolic extract was not able to produce a genotoxic effect. Future studies will be applied to investigate the effect of isolated bioactive compounds from crude extract of this sponge which are potentially useful for cancer therapeutics.
\end{abstract}

Correspondence to: Dr Cinzia Domenicotti, Department of Experimental Medicine, University of Genoa, Via Leon Battista Alberti 2, I-16132 Genoa, Italy

E-mail: cdomeni@medicina.unige.it

${ }^{*}$ Contributed equally

Key words: Agelas oroides, Petrosia ficiformis, sponge extracts, human neuroblastoma, apoptosis, reactive oxygen species, protein kinase $\mathrm{C}$

\section{Introduction}

Sponges (Porifera) are a type of marine fauna that produce bioactive molecules to defend themselves from predators or spatial competitors $(1,2)$. It has been demonstrated that some of these metabolites have a biomedical potential (3) and in particular, Ara-A and Ara-C are clinically used as antineoplastic drugs $(4,5)$ in the routine treatment of patients with leukaemia and lymphoma.

Moreover, in vitro studies have attributed to sponge metabolites several biological activities such as antimicrobial, antifungal, antiviral, neurotoxic and cytotoxic properties (6-11). Some of these bioactive compounds are able to influence cell survival and death, modifying the activity of several enzymes involved in these cellular processes. In fact, it has been found that a polyketide quinone compound, isolated from the marine sponge Xestospongia carbonaria, inhibits protein tyrosine kinase and is cytotoxic for several malignant cell lines (12). Another enzyme inhibitor, okadaic acid, from the marine sponge Halichondria okadai, strongly inhibits a protein phosphatase, inducing cytoskeletal disruption and is a longknown tumour-promoting compound $(13,14)$. Moreover, many authors have attributed to some of these compounds a potential anticancer activity. In particular, Halichondrin B (15-17) has shown a marked in vitro and in vivo anticancer activity against murine melanoma and leukaemia (18) and Dictyostatin-1, isolated from Spongia sp., is cytotoxic for adenocarcinoma and breast cancer cells (19). Laulimalide and Discodermolide, isolated from Cacospongia mycofijiensis and Discodermia dissoluta, respectively $(20,21)$ have demonstrated tubulin hyperstabilizing properties (22) similar to that of paclitaxel used to cure breast, lung and ovarian cancers $(23,24)$.

The Mediterranean sponge Agelas oroides (Schmidt, 1864; Agelasida, Agelasidae) contains pyrrole imidazole alkaloids such as oroidin, cyclooroidin and taurodispacamide A (25) with a good antihistaminic activity and the brominated compounds agelorin A and B with an antibiotic activity against Bacillus subtilis and Micrococcus luteus (26).

Petrosia ficiformis (Poiret, 1789; Haplosclerida, Petrosiidae), another Mediterranean sponge, is known to 
contain a number of highly toxic and anti-HIV active polyacetylenes such as the petrosyformynes and petrosynol (27), and its cytotoxicity has been demonstrated on human red blood cells (10).

The aim of the present work is to analyse the effect of methanolic crude extracts from the Mediterranean sponge species A. oroides and $P$. ficiformis on two human neuroblastoma (NB) cell lines: LAN5 and SK-N-BE(2)-C.

We found that $A$. oroides extract showed a pro-apoptotic effect in LAN5 cells and investigations have been performed to elucidate some molecular mechanisms of this apoptotic pathway.

\section{Materials and methods}

Chemicals. Polyvinylidene difluoride (PVDF) membrane, enhanced chemiluminescence Western blot analysis system, and secondary conjugated horseradish-peroxidase antibodies, which binds first rabbit or mouse antibodies, were supplied by Amersham International (Buckinghamshire, UK).

Rabbit polyclonal antibodies reacting with PKCס and NF-L were from Santa Cruz Biotechnology (Santa Cruz, CA, USA). Mouse monoclonal antibodies reacting with $\mathrm{PKC} \alpha$ and $\varepsilon$ were supplied by AbCam (Cambridgeshire, UK) and anti- $\alpha$ fodrin was from Chemicon International (Germany). Goat anti-rabbit FITC-conjugated antibody was supplied by Upstate cell signaling solutions (NY, USA). The Annexin VFITC apoptosis detection kit was from Biovision Research Products (Mountain View, CA, USA). Protein G-sepharose and dithiothreitol (DTT) were supplied by Pharmacia Biotech (Uppsala, Sweden). [ $\left.\gamma^{-32} \mathrm{P}\right]-\mathrm{ATP}$ (specific activity 3,000 Ci/ mmol) was from Perkin-Elmer Life Sciences. All other reagents were from Sigma Chemicals Co. (St. Louis, MO, USA).

Sponge collection and extraction procedure. Some individuals of the Mediterranean sponges Agelas oroides and Petrosia ficiformis were collected during Winter 2003 from Portofino's Promontory (Ligurian Sea, Italy) from depths of 10 to $20 \mathrm{~m}$ and then frozen at $-20^{\circ} \mathrm{C}$. Samples were then thawed and placed in $0.9 \% \mathrm{NaCl}$ at room temperature. Sponges were then homogenised and centrifuged at $>10,000 \mathrm{rpm}$ for $30 \mathrm{~min}$. The supernatant was filtered, lyophilised and frozen again at $-20^{\circ} \mathrm{C}$. Samples were extracted with methanol $(1: 1)$ on a stirrer for $3 \mathrm{~h}$ or overnight. The supernatant was filtered through a ceramic filter and the solid material was placed again in the solvent for the second and third extraction. The supernatant was then dried using a Rotovapor at $40^{\circ} \mathrm{C}$ with $5-10 \mathrm{ml}$ of distilled water to obtain the crude extract of the two sponge species.

Cell culture. Our experimental model was represented by two human neuroblastoma cell lines: LAN5 and SK-N-BE(2)-C. Cells were maintained in RPMI-1640 medium supplemented with $10 \%$ fetal bovine serum, $2 \mathrm{mM}$ glutamine, $1 \%$ penicillin/ streptomycin, $1 \%$ sodium piruvate, $1 \%$ non-essential aminoacid solution, and $1 \%$ antimycotic solution. Cells were incubated at $37^{\circ} \mathrm{C}$ in a humidified atmosphere of $95 \%$ air and $5 \% \mathrm{CO}_{2}$ and were splitted and seeded in new flasks $\left(75 \mathrm{~cm}^{2}\right)$ every two days to maintain them in log-phase. Cells were treated for 15 and $30 \mathrm{~min}$ with 5,10,20 and $50 \mathrm{ppm}$ of A. oroides or
$P$. ficiformis methanolic crude extracts. Some samples of LAN5 cells were pre-treated for 30 min with $250 \mu \mathrm{M}$ vitamin C, $10 \mu \mathrm{M}$ calpeptin, $20 \mu \mathrm{M}$ z-VAD-fmk.

Annexin V-fluorescein isothiocyanate (FITC)/propidium iodide (PI) staining. This assay is based on the ability of Annexin-V to bind to the phosphatidylserine exposed on the surface of cells undergoing apoptosis and the capacity of propidium iodide to enter cells that have lost their membrane integrity (28). Cells were grown and treated on chamber slides (Iwaki Seiyaku Co., Tokyo, Japan), the medium was discarded, and the cells were incubated in the dark for $5 \mathrm{~min}$ at room temperature with $200 \mu \mathrm{l}$ of $1 \mathrm{X}$ binding buffer, $0.5 \mu \mathrm{g} / \mathrm{ml}$ FITC-labelled recombinant Annexin- $\mathrm{V}$, and $0.5 \mu \mathrm{g} / \mathrm{ml}$ propidium iodide. The cells were observed and counted (5-fields of $\sim 60$ cells) under a fluorescence Leica DIMRB microscope (Leica Microsystems AG, Wetzlar, Germany) using a dual filter set for FITC and rhodamine. To evaluate apoptotic process, we considered the percentage of Annexin-V-positive/propidium iodide-negative cells.

Measurement of reactive oxygen species (ROS) production. After sponge extract exposure, cells were incubated for $20 \mathrm{~min}$ at $37^{\circ} \mathrm{C}$ with $20 \mu \mathrm{M} 2^{\prime}-7^{\prime}$-dichlorofluorescein-diacetate (DCFH-DA), a cell-permeable, nonfluorescent precursor of DCF that can be used as an intracellular probe for oxidative stress $(29,30)$. Accumulation of DCF in the cells was measured by an increase in fluorescence at $530 \mathrm{~nm}$ when the sample was excited at $485 \mathrm{~nm}$. Observations were made with a Leica DIMRB microscope, and a standard set of filters for fluorescein (excitation 460-500 nm, emission 510-560 nm) was used.

$N F-L$ detection. After treatments cells were fixed for $15 \mathrm{~min}$ in $4 \%$ paraformaldehyde (PFA) in $10 \mathrm{mM}$ PBS. Then, cells were permeabilized with $0.1 \%$ Triton $\mathrm{X}-100$ in PBS, and washed three times in $10 \mathrm{mM}$ PBS. Anti-NF-L primary antibody (1:200 dilution in PBS) was added and incubated at room temperature. After washing in PBS, FITC-conjugated secondary antibody was added (1:300) and the cells were incubated for $30 \mathrm{~min}$ in a humidified atmosphere. Slides were mounted with Mowiol 4-88 (Calbiochem, Darmstadt, Germany) and analyzed by Leica DIMRB microscope, using 60x oil-immersion objective.

Single cell gel electrophoresis (Comet assay). We used formamidopyrimidine DNA glycosylase (Fpg)-modified comet assay (31) to evaluate DNA oxidative damage. This test employes the Fpg enzyme, a glycosylase that recognizes and specifically cuts the oxidized bases, principally 8-oxo-guanine, from DNA producing apurinic sites converted in breaks by the associated AP-endonuclease activity. The procedure of Tice and Strauss (32) has been followed with minor modifications. The comet assay protocol was carried out under dim light to prevent any additional DNA damage. After treatments, cells were trypsinized and cell suspensions $\left(15 \times 10^{3}\right.$ cells $)$ were mixed with low melting point agarose $(0.5 \%$ in PBS) and spread on slides with a thin layer of normal melting point agarose (1.5\% in PBS). The slides were washed three times in enzyme buffer $\left(50 \mathrm{mM} \mathrm{Na}_{3} \mathrm{PO}_{4}, 10 \mathrm{mM}\right.$ EDTA, $100 \mathrm{mM}$ 
LAN5

A)

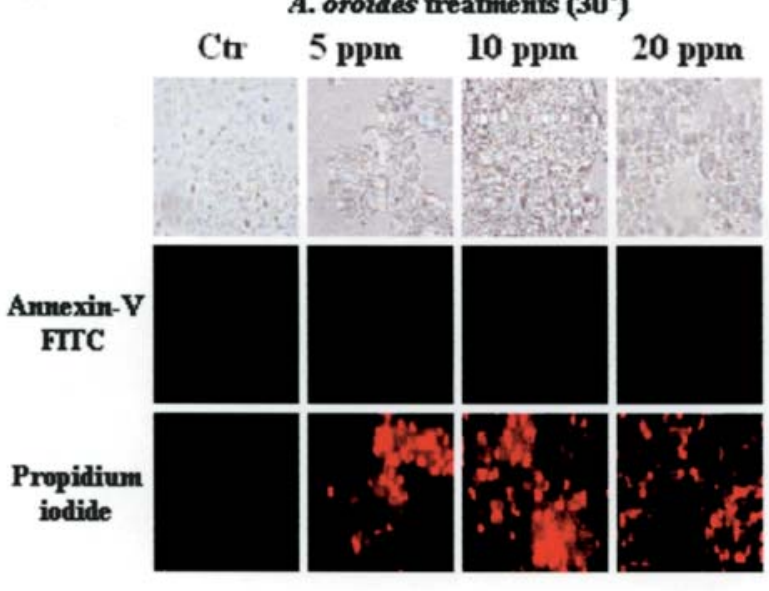

C)

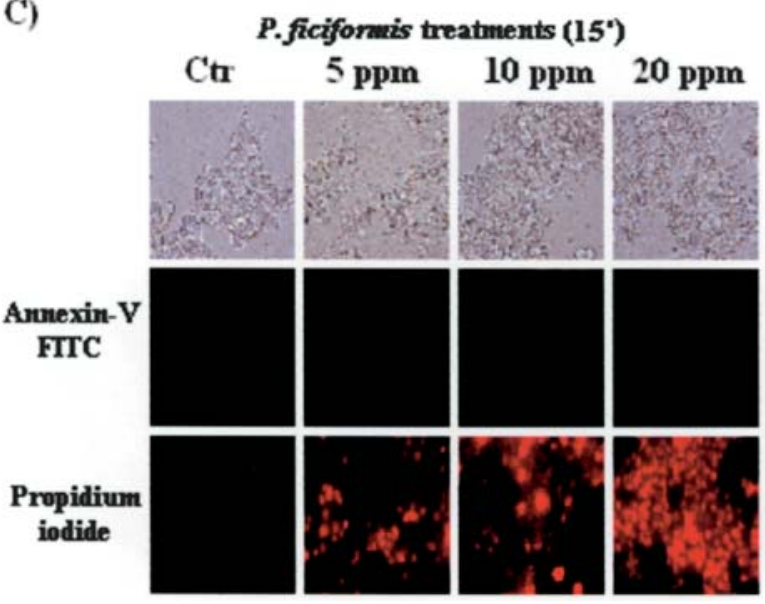

B)

SK-N-BE(2)-C

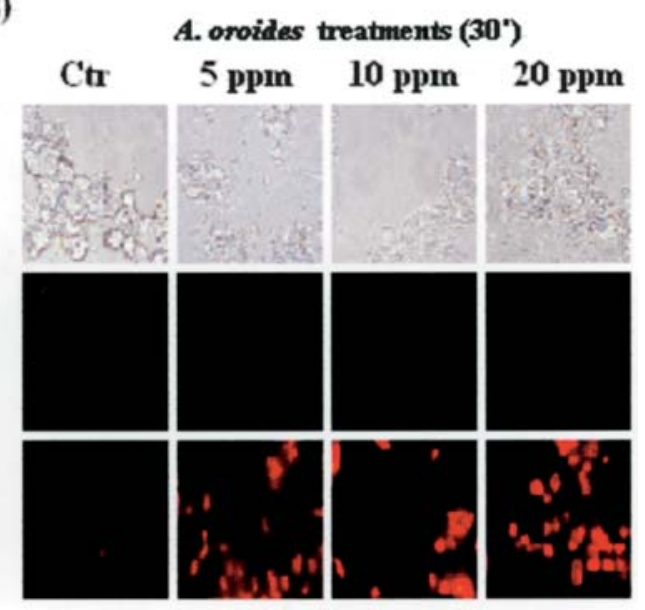

D)

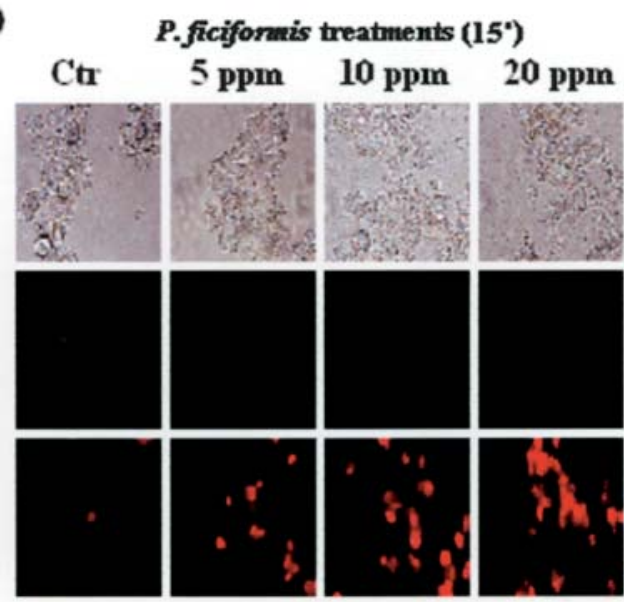

Figure 1. A. oroides and P. ficiformis methanolic crude extracts differentially influenced human neuroblastoma cell viability. Apoptotic or necrotic changes were tested by fluorescence microscopy in LAN5 (A and C) and SK-N-BE(2)-C cells (B and D). Panels A and B show NB cells treated for 30 min with 5, 10 and 20 ppm of A. oroides extract. Panels C and D show NB cells treated for 15 min with 5, 10 and 20 ppm of $P$. ficiformis extract. Apoptosis or necrosis were assessed by counting the number of Annexin-V- or propidium iodide-positive cells. The lower subpanels show representative images obtained by fluorescence microscopy analysis of propidium iodide-positive cells in all conditions of treatment. The middle subpanels are representative of images obtained by fluorescence microscopy analysis of Annexin-V-FITC-positive cells. The upper subpanels show images of cells observed by standard filters.

$\mathrm{NaCl}, \mathrm{pH} 7.5)$, drained and incubated with $50 \mu 1$ of either buffer or Fpg $(1 \mu \mathrm{g} / \mathrm{ml}$ in enzyme buffer $)$ in the dark for $30 \mathrm{~min}$ at $37^{\circ} \mathrm{C}$. The slides were placed in a horizontal gel box near the anode end, and covered with electrophoretic buffer (300 mM NaOH, 1 mM EDTA, pH>13.0); after 30 min, slides were subjected to an electric field of $300 \mathrm{~mA}$ for $40 \mathrm{~min}$. Finally, slides were coated with neutralisation buffer $(0.4 \mathrm{M}$ Tris-HCl pH 7.5), dried and incubated for $10 \mathrm{~min}$ in absolute ethanol. Slides were then stained with $50 \mu 1 \mathrm{lX}$ ethidium bromide staining solution, covered with a cover slip and analysed by means of a fluorescence microscope (Leica DIMRB) with an excitation filter of 515-560 $\mathrm{nm}$ and a barrier filter of $590 \mathrm{~nm}$.

Total protein extraction. After washing, cells were treated with a lysis-buffer containing protease inhibitors and $0.25 \%$ Triton. Cells were detached and then collected in tubes, sonicated and finally centrifuged at 40,000 rpm for $30 \mathrm{~min}$ at $4{ }^{\circ} \mathrm{C}$. Total proteins were determined by means of the Lowry method and using bovine serum albumin as standard.
Immunoblot analysis. Proteins $(50 \mu \mathrm{g})$ were denatured in 3.5X Laemmli buffer and then subjected to 7\% and 8\% SDSpolyacrylamide gel electrophoresis for $\alpha$-fodrin and PKCs respectively, followed by electroblotting (100 V for $1 \mathrm{~h}$ ) onto a PVDF membrane. Subsequently, the PVDF membrane was washed in distilled water and marked with Ponceau solution to verify the blotting. Immunodetection was performed using specific antibodies. After incubation with secondary antibody, the immunoblots were detected by means of an enhanced chemiluminescence system. Changes in protein levels were estimated by densitometric analysis.

$P K C$ activity assay. Classic and novel PKC isoforms were immunoprecipitated with specific antibodies and protein G-sepharose using $50 \mu \mathrm{g}$ of protein sample. The beads were washed three times in a washing buffer containing $10 \mathrm{mM}$ Tris- $\mathrm{HCl}, 150 \mathrm{mM} \mathrm{NaCl}, 10 \mathrm{mM} \mathrm{MgCl}$ and $0.5 \mathrm{mM}$ DTT. The activity assay of classic isoenzymes was performed by adding $15 \mu \mathrm{l}$ of washing buffer supplemented with $0.1 \mathrm{mM}$ ATP, $\left[\gamma^{-32}\right.$ P ATP $(2 \mu \mathrm{Ci}$ per sample $), 1 \mu \mathrm{g}$ of phosphatidyl- 


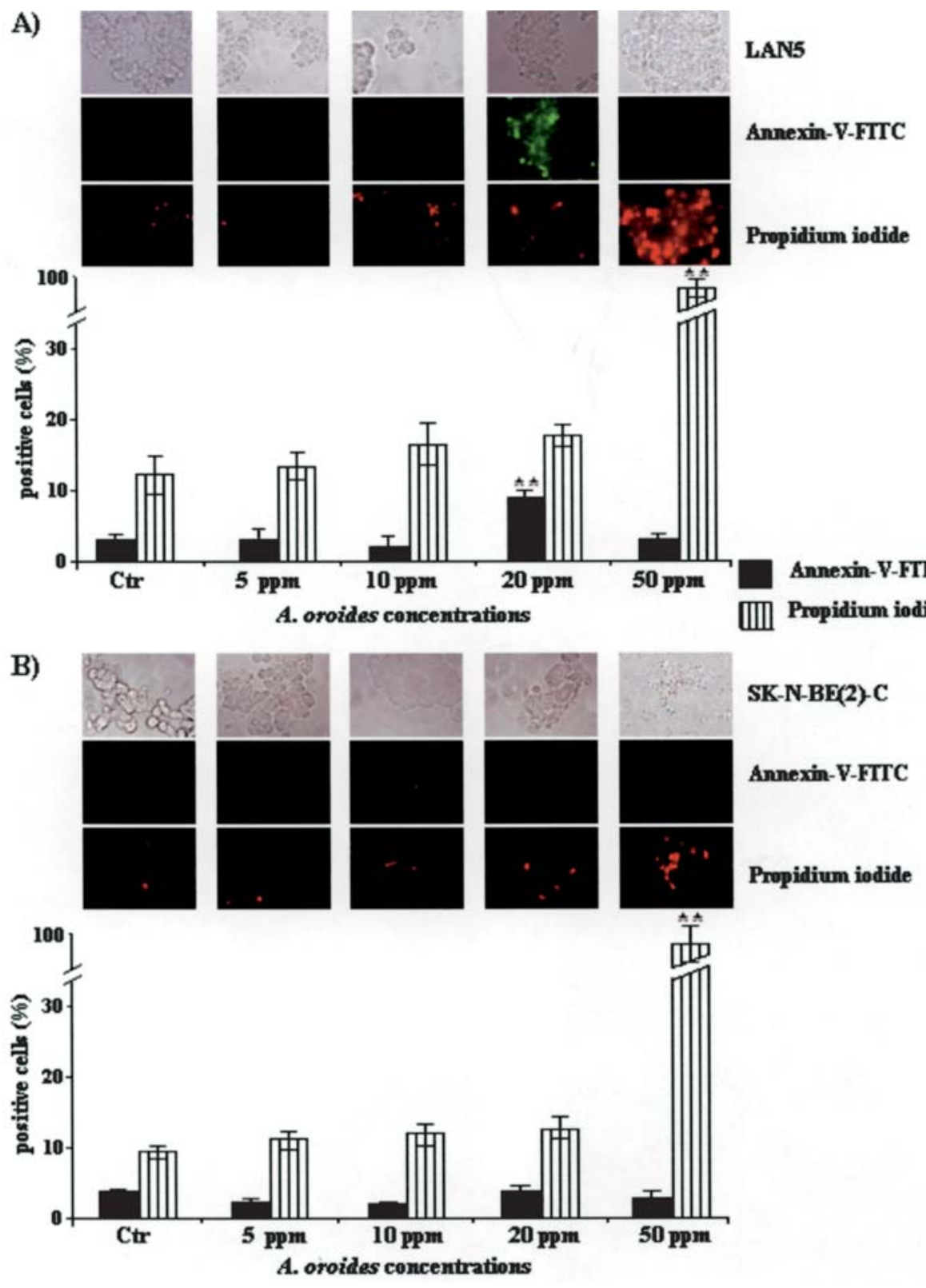

Figure 2. The $20 \mathrm{ppm}$ concentration of A. oroides extract induced apoptosis of LAN5 cells. Apoptosis and necrosis were tested by fluorescence microscopy in LAN5 (A) and SK-N-BE(2)-C cells (B). Neuroblastoma cells were treated for 15 min with 5, 10, 20 and 50 ppm of A. oroides extract. Apoptosis and necrosis were assessed by counting the number of Annexin- $\mathrm{V}$ - and propidium iodide-positive cells. The lower panels show representative images obtained by fluorescence microscopy analysis of propidium iodide-positive cells in all conditions of treatment. The middle panels are representative of images obtained by fluorescence microscopy analysis of Annexin-V-FITC-positive cells. The upper panels show images of cells observed by standard filters. The histograms are representative of three independent experiments. ${ }^{* *} \mathrm{p}<0.01 \mathrm{vs}$. control (Ctr).

serine, $0.4 \mu \mathrm{g}$ of dioleoylglycerol, $0.5 \mathrm{mM} \mathrm{CaCl}_{2}$ and $10 \mu \mathrm{g}$ of $\mathrm{H} 1$ histone as substrate (33). A reaction mixture without calcium was used to evaluate the activity of novel PKC isoforms. The reaction was carried out at $30^{\circ} \mathrm{C}$ for $10 \mathrm{~min}$ using histone as a substrate, then stopped by adding $3.5 \mathrm{X}$ Laemmli buffer. The reaction mixtures were loaded onto $12.5 \%$ SDS-polyacrylamide gel, which was dried and then exposed to an autoradiographic film for $24 \mathrm{~h}$ at $-80^{\circ} \mathrm{C}$. The relative intensity of phosphorylated substrates was measured by densitometric analysis.

Statistical analysis. Results were expressed as mean \pm SD from at least three independent experiments. The statistical significance of parametric differences among sets of experimental data was evaluated by One-way ANOVA and Bonferroni's test for multiple comparisons.

\section{Results}

A. oroides and P. ficiformis methanolic crude extracts differentially influence human neuroblastoma cell survival. To evaluate the impact of $A$. oroides and $P$. ficiformis methanolic crude extracts on cell survival, we have treated two human neuroblastoma cell lines, LAN5 and SK-N-BE(2)-C, with 5, 10 and $20 \mathrm{ppm}$ of the sponge extracts for 15 and $30 \mathrm{~min}$.

The concentrations of 5, 10 and $20 \mathrm{ppm}$ of $A$. oroides were highly cytotoxic for both cell lines exposed for $30 \mathrm{~min}$ (Fig. 1A and B) and these effects were compared to those 
A)

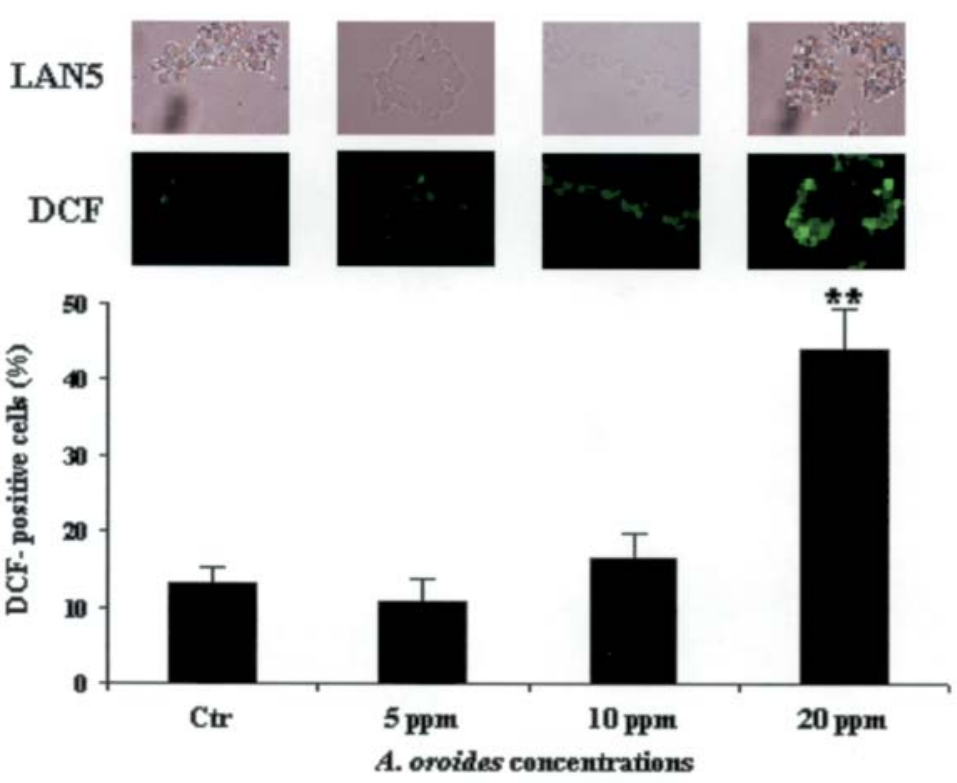

B)
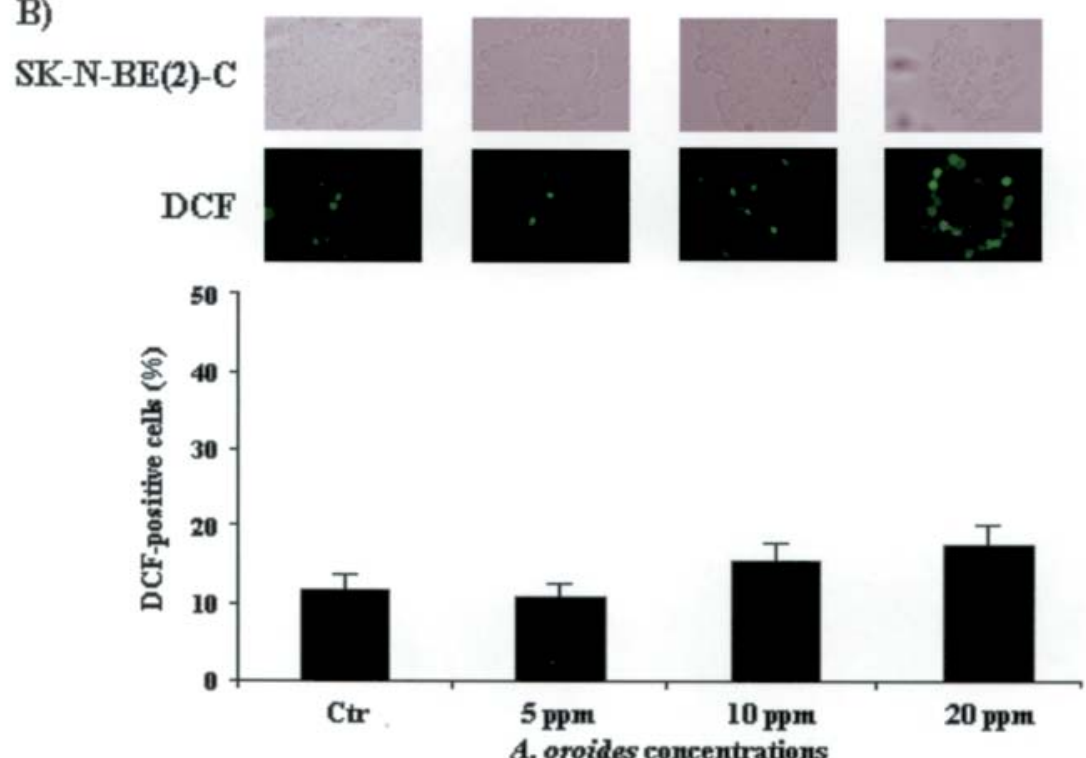

Figure 3. A. oroides extract increased ROS production in LAN5 cells. ROS levels were measured by fluorescence microscopy in LAN5 (A) and SK-N-BE(2)-C (B) untreated cultures and in cells after 15 min of incubation with different concentrations (5-20 ppm) of A. oroides extract. ROS generation was estimated by counting the number of DCF-positive cells. The lower panels show representative images obtained by fluorescence microscopy analysis of DCF-positive cells in all conditions of treatment. The upper panels show images of cells observed by standard filters. The histograms are representative of five independent experiments. Data are given as mean $\pm \mathrm{SD} .{ }^{* *} \mathrm{p}<0.01 \mathrm{vs}$. control cells compared by ANOVA, followed by the Bonferroni's test.

determined by $P$. ficiformis which had already induced necrosis of both NB cell lines after 15 min of treatment (Fig. 1C and D). As expected, a marked cell death of these NB cells was found also after $30 \mathrm{~min}$ treatment with $P$. ficiformis (data not shown).

Interestingly, we observed in both cell lines a time- and dose-dependent effect of $A$. oroides extract after $15 \mathrm{~min}$ of cell exposure (Fig. 2): in particular, 10 and 20 ppm concentrations induced a light increase of necrotic cells versus the basal conditions, while $50 \mathrm{ppm}$ induced a marked enhancement of propidium iodide-positive cells comparable to that observed at the longest time $(30 \mathrm{~min})$ of treatment with $20 \mathrm{ppm}$.

In addition, while no changes in apoptotic marker were detected in SK-N-BE(2)-C cells (Fig. 2B), a 20 ppm concentration of $A$. oroides extract induced a 1.5 -fold increase (vs. control) in Annexin-V-positivity of LAN5 cells (Fig. 2A).
A 20-ppm concentration of A. oroides extract causes ROS overproduction in LAN5 cells. It has been widely demonstrated that sponge crude extracts can modulate cell oxidative state $(34,35)$ and for this reason we monitored ROS levels by measuring the number of DCF-positive cells.

Both NB cells were characterised by basal ROS production (12-13\%) and $15 \mathrm{~min}$ exposure to $5 \mathrm{ppm}$ sponge extract did not change the control redox state. The concentration of $10 \mathrm{ppm}$ induced a light enhancement of ROS levels (Fig. 3) that became 2.5 fold increased after exposure of LAN5 to $20 \mathrm{ppm}$ (Fig. 3A).

ROS overproduction and apoptosis of LAN5 cells is prevented by vitamin $C$ or calpain or caspase inhibition. The percentages of DCF-positive and Annexin-V-positive LAN5 cells exposed 
A)

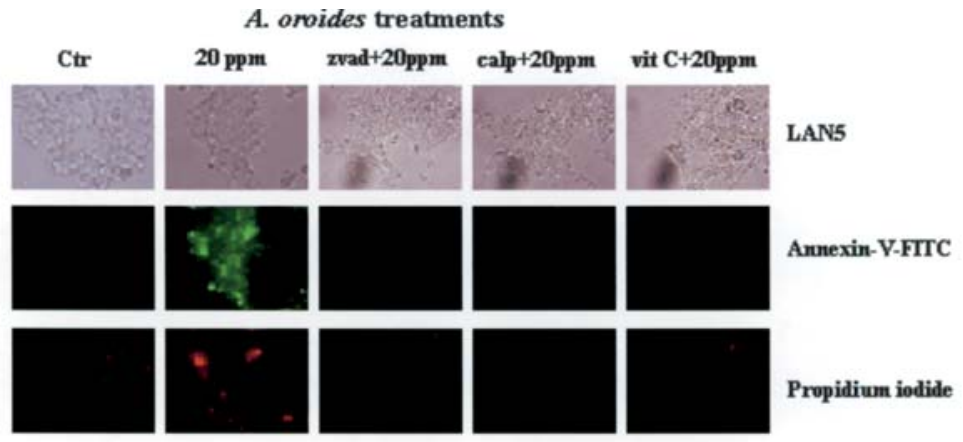

B)

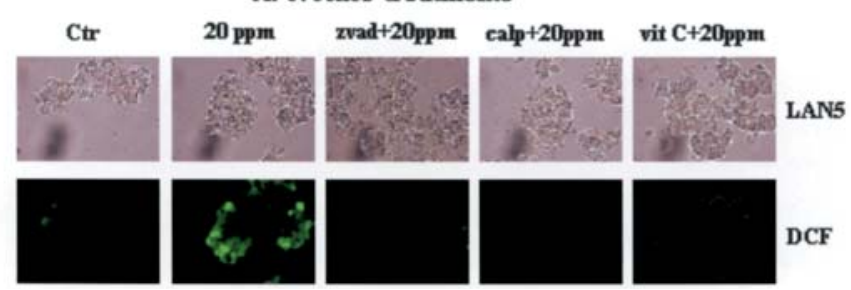

Figure 4. Pre-treatments of LAN5 cells with calpain or caspase inhibitors or with vitamin C totally prevented cell death and ROS overproduction induced by A. oroides extract. Apoptosis, necrosis (A) and ROS generation (B) were evaluated by fluorescence microscopy in untreated cultures of LAN5, in cells after 15 min incubation with $20 \mathrm{ppm}$ of $A$. oroides and in cultures pre-treated for 30 min with $10 \mu \mathrm{M}$ calpeptin, or $20 \mu \mathrm{M} \mathrm{z}$-VAD-fmk or $250 \mu \mathrm{M}$ vitamin C. Apoptosis and necrosis were assessed by showing Annexin-V-and propidium iodide-positive cells. ROS generation was estimated by showing DCF-positive cells. In panel A the lower subpanels are representative images obtained by fluorescence microscopy analysis of propidium iodide-positive cells. The middle subpanels are representative images obtained by fluorescence microscopy analysis of Annexin-V-FITC-positive cells. The upper sub-panels show cells observed by standard filters. In panel B the lower sub-panels are representative images obtained by fluorescence microscopy analysis of DCF-positive cells in all conditions of treatment. The upper subpanels show cells observed by standard filters.

A)

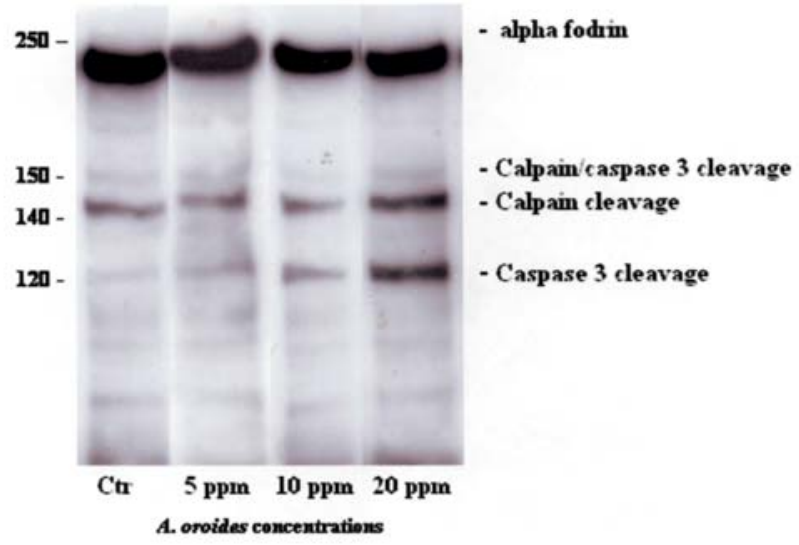

B)
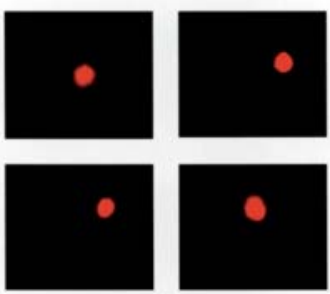

no Fgp

Ctr

A. orot

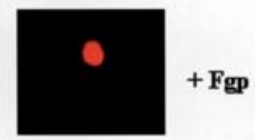

20 ppm

Figure 5. A. oroides extract induced the activation of calpain- and caspasedependent pathways without oxidative or non-oxidative DNA damage. LAN5 cells were treated for 15 min with 5, 10 and $20 \mathrm{ppm}$ of methanolic crude extracts of Agelas oroides; then, cells were harvested and protein extracts were subjected to immunoblot analysis. Panel A shows the determination of calpain and caspase activities by analysis of $\alpha$-fodrin. The immunoblot shown is representative of three independent experiments. Panel B shows fgp-modified comet assay in LAN5 cells treated for $15 \mathrm{~min}$ with $20 \mathrm{ppm}$ of A.oroides.

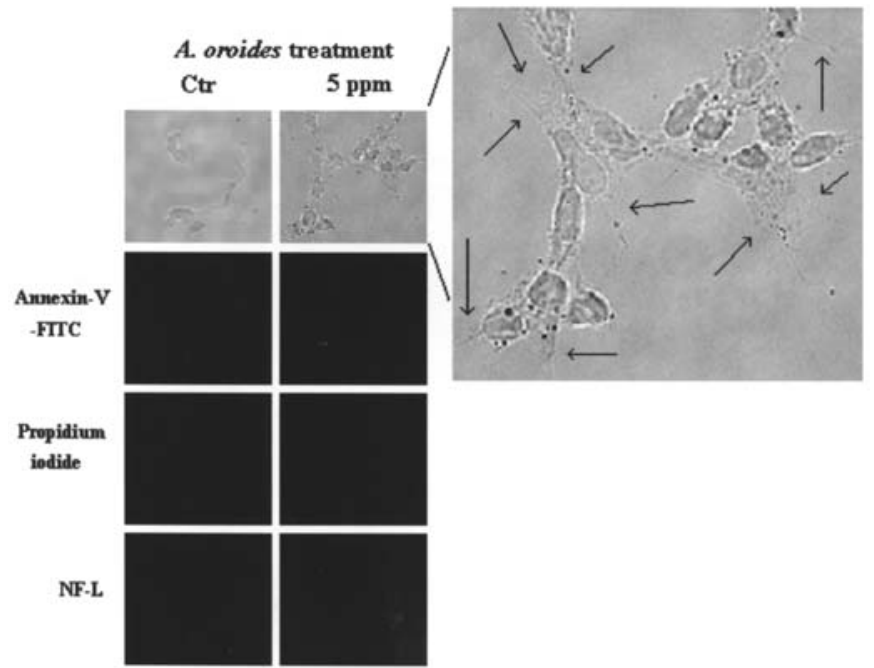

Figure 6. The 5-ppm concentration of A. oroides extract induced morphological changes in LAN5 which are not associated to apoptosis, necrosis or NF-L labelling. Apoptotic or necrotic changes were assessed by showing Annexin-V or propidium iodide staining, the NF-L labelling was tested by fluorescence microscopy analysis. The first panels from the top are representative images of cells observed by standard filters, the second and third panels are representative images of Annexin- $\mathrm{V}$ and propidium iodide staining respectively. The fourth panel shows images of NF-L labelling.

to $20 \mathrm{ppm}$ of A. oroides extract were drastically suppressed by $250 \mu \mathrm{M}$ vitamin $\mathrm{C}$ or $10 \mu \mathrm{M}$ calpeptin, a calpain inhibitor or $20 \mu \mathrm{M} \mathrm{zVAD}$, a pan-caspase inhibitor (Fig. 4).

A. oroides extract induces apoptosis without DNA oxidative damage. To confirm the apoptotic process induced in LAN5 
A)

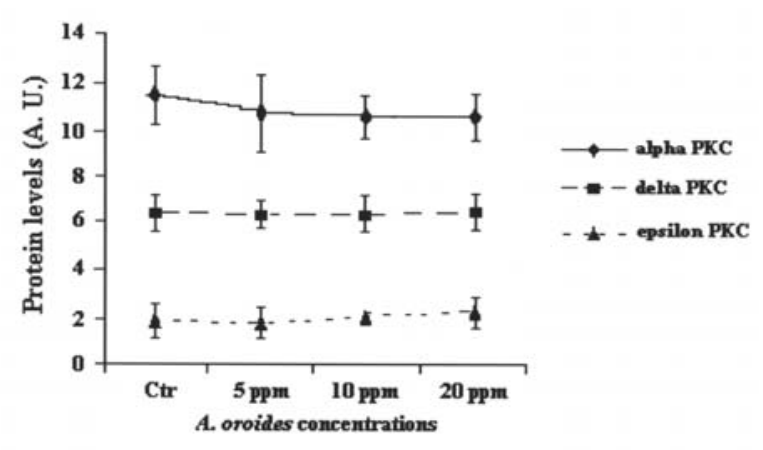

B)

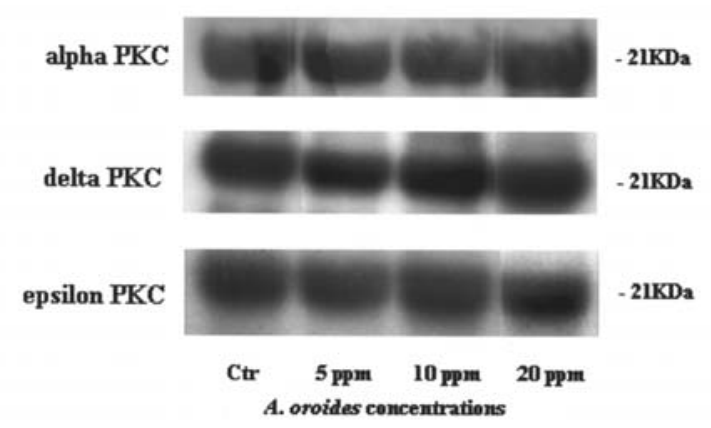

Figure 7. A. oroides extract did not modify PKC expression levels and functional activities. LAN5 cells were treated with A. oroides extract at different concentration $(5,10,20 \mathrm{ppm})$; cells were then harvested and protein extracts were subjected to immunoblot analysis (A) and activity assay (B) of $\mathrm{PKC}$ isoforms. Panel A shows the graph of $\mathrm{PKC} \alpha, \delta$ and $\varepsilon$ protein levels obtained after densitometric analysis of immunoblots. The values are the mean $\pm \mathrm{SD}$ of three determinations. Panel B shows the autoradiographs of $\mathrm{H} 1$ histone phosphorylated by $\mathrm{PKC} \alpha, \delta$ and $\varepsilon$. The autoradiographs shown are representative of three independent experiments.

cells exposed to $20 \mathrm{ppm}$ of $A$. oroides extract we have measured the expression levels of $\alpha$-fodrin. This cytoskeletal substrate can be degraded by caspase 3 into smaller fragments of 150 and $120 \mathrm{kDa}$ and by calpain into fragments of 150 and $145 \mathrm{kDa}$ $(36,37)$. In the present study conditions, a 20 ppm concentration caused a marked formation of the fragments of 145 and $120 \mathrm{kDa}$ as consequence of calpain and caspase cleavage (Fig. 5A). Comet assay showed that apoptosis of LAN5 cells was not accompanied by oxidative or non-oxidative DNA damage (Fig. 5B).

A 5 ppm concentration of A. oroides extract causes membrane alterations in LAN5 cells. Interestingly, $5 \mathrm{ppm}$ induced the formation of some membrane extensions in LAN5, whose phenotype was associated neither to Annexin-V-FITC staining nor propidium iodide labelling (Fig. 6). To investigate whether these membrane extensions were the result of neuronal differentiation, the expression level of NF-L was examined and we found that this event was not accompanied by NF-L labelling (Fig. 6).

A. oroides does not influence PKC expression levels and activities. The expression levels of PKC $-\alpha,-\delta$ and $-\varepsilon$, whose protein levels are more expressed in this kind of tumour, were not significantly modified after sponge extract treatment (Fig. 7A). Enzymatic activities of the three isoforms tested were not affected by A. oroides extract treatment (Fig. 7B).

\section{Discussion}

Considering the pharmaceutical potential of many bioactive molecules, a wide number of studies have been carried out to examine the effects of marine sponge crude extracts and isolated molecules on several kinds of tumoural cell lines as suitable bioassays. Screening of extracts from marine sponges is a common approach to identify possible compounds of biomedical importance $(38,39)$.

In the present study, the effects of the methanolic crude extracts of $A$. oroides on SK-N-BE(2)-C and LAN5 human NB cell lines have been investigated and compared to those produced by $P$. ficiformis. We have found that 10 and $20 \mathrm{ppm}$ concentrations of $A$. oroides or $P$. ficiformis extracts were able to induce a marked cell death of NB lines but at quite different times of exposure.

In fact, comparing the impact of the same concentrations of the two sponge extracts on NB cells tested, we have observed that the cytotoxic effect induced by $P$. ficiformis was already evident after $15 \mathrm{~min}$ and at lower concentration (5 ppm); while, a similar effect was appreciable for A. oroides only after 30 min of treatment.

Moreover, A. oroides had a time- and dose-dependent cytotoxic effect inducing an increase in apoptosis of LAN5 cells after $15 \mathrm{~min}$ of exposure to $20 \mathrm{ppm}$.

Recently, it has been reported that Petrotetrayndiol A, a polyacetylene isolated from the sponge Petrosia sp., induced caspase-dependent apoptosis in SK-MEL-2 human melanoma cells (40), Lembehyne A, from Haliclona sp., led differentiation of Neuro 2A cells (41) and Labuanine A, from Biemna fortis, caused in Neuro 2A cells multipolar neuritogenesis and arrested cell cycle at the G2/M phase (42). Many studies in the scientific literature have therefore investigated the effects of isolated molecules from sponge extracts on murine and less frequently on human neuroblastoma cells (43).

Our previous reports have demonstrated that the apoptotic process of human NB cells is strictly related to intracellular ROS overproduction (44) and also in this context, we have found that a 2.5-fold increase of ROS levels was accompanied by the appearance of apoptotic features in LAN5 cells treated with 20 ppm of A. oroides.

The present study shows that the apoptosis of LAN5 triggered by $A$. oroides extract is of oxidative nature, since the prevention of this phenomenon is obtained after pretreatment with antioxidant vitamin C. Moreover, these apoptotic features are abolished by a calpain or caspase inhibitors, which are also able to counteract ROS generation.

Inhibition of caspase activation has been recently demonstrated to block ROS production (45), suggesting that the generation of oxidant species during apoptosis may be caspasedependent.

Therefore, our results demonstrate that $20 \mathrm{ppm}$ of $A$. oroides induces calpain- and caspase-dependent apoptosis of LAN5 cells and these findings are confirmed by the cleavage of $\alpha$ fodrin that leads the formation of 120 and $145 \mathrm{kDa}$ fragments, markers of calpain and caspase 3 activation $(36,37)$.

A. oroides-induced oxidative death of LAN5 cells is not accompanied by DNA oxidative damage thereby suggesting a potential anticancer activity of this extract since it shows apoptotic but not genotoxic properties. In fact, we observe 
in LAN5 cells the translocation of phosphatidylserine to the outer cell membrane and the proteolytic activation of caspases as marker events of apoptosis but we don't detect any DNA single-strand breaks.

On the other hand, the lower and not cytotoxic concentration (5 ppm) of A. oroides induced morphological changes in LAN5 cells exposed for $15 \mathrm{~min}$ and these membrane extensions were not associated to apoptosis or necrosis.

Many authors have reported that long-time treatment (24-48 h) with several sponge crude extracts induces alterations of cell morphology and microtubule organization $(41,42,46)$. In the present conditions, membrane alterations were a more precocious event than that observed by other studies $(18,42)$; for this reason, we hypothesize that $A$. oroides extract might specifically modify cytoskeletal proteins but further analyses are needed. Certainly, we have excluded that these morphological changes are the result of neuronal differentiation because the event is not characterized by NF-L presence.

Most bioactive metabolites isolated from sponges are inhibitors of key enzymes, which mediate or produce mediators of intracellular or intercellular messengers involved in the pathogenesis of human diseases $(12,14,47)$.

It has been demonstrated that some isolated sponge compounds are inhibitors of PKCs (48) and PKC inhibitors have attracted interest worldwide as there is evidence that high levels of PKC enzyme are involved in the pathogenesis of many human diseases and in tumour development (49).

Our previous studies have demonstrated that PKC isoforms are specifically affected by intracellular ROS generation and apoptosis of NB cells was mediated by an increase in the activity of $\delta$ and a concomitant inactivation of $\alpha$ isoform (50).

In the present study, no changes were observed in protein levels and activities of PKC isoenzymes mainly expressed in neuroblastoma. Additional study is in progress to identify the action of single bioactive compounds from the methanolic crude extract of $A$. oroides responsible for the morphological changes observed in LAN5 cells. These studies might provide evidence of marine sponges as a promising therapeutic approach for this kind of tumour.

\section{Acknowledgements}

We thank Mr. Giuseppe Catalano (DIMES-University of Genoa), Drs Marco Faimali and Giuliano Greco (ISMAR-CNR Genoa) and Dr Fiorenzo Lorenzi (ASL) for their technical assistance. This study was supported by grants from G. Gaslini Institute, from Genoa University (ex 60\%), from the Italian Ministry of University: PRIN nos. 2004063943_001 and 2004068552_002 and from Ministry of Agriculture and Forestry Politics.

\section{References}

1. Braekman JC and Dalose D: Chemical defense in sponges. Pure Appl Chem 58: 357-364, 1986.

2. Pawlik JR, McFall G and Zea S: Does the odor from sponges of the genus Ircinia protect them from fish predators? J Chem Ecol 28: 1103-1115, 2002.

3. Munro MHG, Blunt JW, Dumdei EJ, Hickfort SJH, Lill RE, Li S, Battershill CN and Duckworth AR: The discovery and development of marine compounds with pharmaceutical potential. J Biotechnol 70: 15-25, 1999.
4. Munro MHG, Blunt JW, Lake RJ, Litaudon M, Battershill CN and Page MJ: From seabed to sickbed: what are the prospects? In: Sponge in Time and Space: Biology, Chemistry, Paleontology. Van Soest RWM, van Kempen TG and Braekman JC (eds). Balkema AA, Rotterdam, pp473-484, 1994.

5. Schmitz FJ: Cytotoxic compounds from sponges and associated microfauna. In: Sponge in Time and Space: Biology, Chemistry, Paleontology. Van Soest RWM, van Kempen TG and Braekman JC (eds). Balkema AA, Rotterdam, pp485-496, 1994.

6. Fusetani $\mathrm{N}$ and Matsunaga S: Bioactive sponge peptides. Chem Rev 93: 1793-1806, 1993.

7. Berlinck RGS, Ogawa CA, Almeida AMP, Sanchez MAA, Malpezzi ELA, Costa LV, Hajdu E and Freitas JC: Chemical and pharmacological characterization of halitoxin from Amphimedon viridis (Porifera) from the southeastern Brazilian coast. Comp Biochem Physiol 115: 155-163, 1996.

8. Rangel M, De Sanctis B, Freitas JC, Polatto JM, Granato AC, Berlinck RGS and Hajdu E: Cytotoxic and neurotoxic activities in extracts of marine sponges (Porifera) from southeastern Brazilian coast. J Exp Mar Biol Ecol 262: 31-40, 2001.

9. Mebs D, Weiler I and Heinke HF: Bioactive proteins from marine sponges: screening of sponge extracts for hemagglutinating, haemolytic, ichthyotoxic and lethal properties and isolation and characterization of haemagglutinins. Toxicon 23: 955-962, 1985.

10. Sepcic K, Batista U, Vacelet J, Macek P and Turk T: Biological activities of aqueous extracts from marine sponges and cytotoxic effects of 3-alkylpyridinium polymers from Reniera sarai. Comp Biochem Physiol 117: 47-53, 1997.

11. Thompson JE, Walker RP and Faulkner DJ: Screening and bioassays for biologically active substances from forty marine sponge species from San Diego, CA, USA. Mar Biol 88: 11-21, 1985.

12. Lee RH, Slater DL, Moretti R, Alvi KA and Crews P: Marine polyketide inhibitors of protein tyrosine kinase. Biochem Biophys Res Commun 184: 765-772, 1992.

13. Garcia-Sainz JA, Macias-Silva M and Romero-Avila MT: Effect of okadaic acid on hormone-stimulated and mastoporanstimulated phosphoinositide turnover in isolated rat hepatocytes. Biochem Biophys Res Commun 179: 852-858, 1991.

14. Tachibana K, Scheuer PJ, Tsukitani Y, Kikuchi H, van Engen D, Clardy J, Gopichand Y and Schmitz FJ: Okadaic acid, a cytotoxic polyether from two marine sponges of the genus Halichondria. J Am Chem Soc 103: 2469-2471, 1981.

15. Hirata Y and Uemura D: Halichondrins: antitumor polyether macrolides from a marine sponge. Pure Appl Chem 58: 701-710, 1986.

16. Uemura D, Takahashi K, Yamamoto T, Katayama C, Tanaka J, Okumura Y and Hirata Y: Norhalichondrin A: an antitumor polyether macrolide from a marine sponge. J Am Chem Soc 107: 4796-4798, 1985.

17. Pettit GR, Herald CL, Boyd MR, Leet JE, Dufresne C, Doubek DL, Schmidt JM, Cerny RL, Hooper JN and Rützler KC: Isolation and structure of the cell growth inhibitory constituents from the western pacific marine sponge Axinella sp. J Med Chem 34: 3339-3340, 1991.

18. Towle MJ, Salvato KA, Budrow J, Wels BF, Kuznetsov G, Aalfs KK, Welsh S, Zheng W, Seletsky BM, Palme MH, Habgood GJ, Singer LA, Di Pietro LV, Wang Y, Chen JJ, Quincy DA, Davis A, Yoshimatsu K, Kishi Y, Yu MJ and Littlefield BA: In vitro and in vivo anticancer activities of synthetic macrocyclic ketone analogues of Halichondrin B. Cancer Res 61: 1013-1021, 2001.

19. Isbrucker RA, Cummins J, Pomponi SA, Longley RE and Wright AE: Tubulin polymerizing activity of dictyostatin-1, a polyketide of marine sponge origin. Biochem Pharmacol 66: 75-82, 2003.

20. Mooberry SL, Tien G, Hernandez AH, Plubrukarn A and Davidson BS: Laulimalide and isolaulimalide, new paclitaxellike microtubule-stabilizing agents. Cancer Res 59: 653-660, 1999.

21. Kowalski RJ, Giannakakou P, Gunasekera SP, Longley RE, Day BW and Hamel E: The microtubule stabilizing agent Discodermolide competitively inhibits the binding of paclitaxel (Taxol) to tubulin polymers, enhances tubulin nucleation reactions more potently than paclitaxel, and inhibits the growth of paclitaxel resistant cells. Mol Pharmacol 52: 613-622, 1997.

22. Schwartsmann G, Brondani Da Rocha A, Berlinck RG and Jimeno J: Marine organisms as a source of new anticancer agents. Lancet Oncol 2: 221-225, 2001. 
23. Khayat D, Antoine EC and Coeffie D: Taxol in the management of cancers of the breast and the ovary. Cancer Invest 18: 242-260, 2000.

24. Calderoni A and Cerny T: Taxanes in lung cancer: a review with focus on the European experience. Crit Rev Oncol Hematol 38: 105-127, 2001.

25. Fattorusso E and Taglialatela-Scafati O: Two novel pyrroleimidazole alkaloids from the Mediterranean sponge Agelas oroides. Tetrahedron Lett 41: 9917-9922, 2000.

26. König GM and Wright AD: Agelorins A and B, and 11-epifistularin-3, three new antibacterial fistularin-3 derivatives from the tropical marine sponge Agelas oroides. Heterocycles 36: 1351-1358, 1993.

27. Bringmann G, Lang G, Steffens S and Schaumann K: Petrosifungins A and B, novel cyclodepsipeptides from a spongederived strain of Penicillium brevicompactum. J Nat Prod 67: 311-315, 2004.

28. Vermes I, Haanen C, Steffens-Nakken H and Reutelingsperger C: A novel assay for apoptosis. Flow cytometric detection of phosphatidylserine expression on early apoptotic cells using fluorescein labelled Annexin V. J Immunol Methods 184: 39-51, 1995.

29. Le Bel CP, Ischiropoulos H and Bondy SC: Evaluation of the probe $2^{\prime}, 7^{\prime}$-dichlorofluorescein as an indicator of reactive oxygen species formation and oxidative stress. Chem Res Toxicol 5: 227-231, 1992.

30. Ellerby LM and Bredesen DE: Measurement of cellular oxidation, reactive oxygen species, and antioxidant enzymes during apoptosis. Methods Enzymol 322: 413-421, 2000.

31. Cavallo D, Ursini CL, Carelli G, Iavicoli I, Ciervo A, Perniconi B, Rondinone B, Gismondi M and Iavicoli S: Occupational exposure in airport personnel: characterization and evaluation of genotoxic and oxidative effects. Toxicology 223: 26-35, 2006.

32. Tice RR and Strauss GH: The single cell gel electrophoresis/ comet assay: a potential tool for detecting radiation-induced DNA damage in humans. Stem Cells 13: 207-214, 1995.

33. Pessino A, Passalacqua M, Sparatore B, Patrone M, Melloni E and Pontremoli S: Antisense oligodeoxynucleotide inhibition of $\delta$ protein kinase $\mathrm{C}$ expression accelerates induced differentiation of murine erythroleukaemia cells. Biochem J 312: 549-554, 1995.

34. Nakagawa H, Murata M, Tachibana K and Shiba T: Screening of epiphytic dinoflagellates for radical scavenging and cytotoxic activities. Phycol Res 46: 9-12, 1998.

35. Guzmán S, Gato A and Calleja JM: Antiinflammatory, analgesic and free radical scavenging activities of the marine microalgae Chlorella stigmatophora and Phaeodactylum tricornutum. Phytother Res 15: 224-230, 2001.

36. Nath R, Raser KJ, Stafford D, Hajimohammadreza I, Posner A, Allen H, Talanian RV, Yuen P, Gilbertsen RB and Wang KK: Non-erythroid alpha-spectrin breakdown by calpain and interleukin 1 beta-converting-enzyme-like protease(s) in apoptotic cells: contributory roles of both protease families in neuronal apoptosis. Biochem J 319: 683-690, 1996.

37. Wang KK, Posmantur R, Nath R, McGinnis K, Whitton M, Talanian RV, Glantz SB and Morrow JS: Simultaneous degradation of alphaII- and betaII-spectrin by caspase 3 (CPP32) in apoptotic cells. J Biol Chem 273: 22490-22497, 1998.
38. Blunt JW, Munro MHG, Battershill CN, Copp BR, McCombs JD, Perry NB, Prinsep M and Thompson AM: From the antarctic to the antipodes; $45^{\circ}$ of marine chemistry. New J Chem 14: 761-775, 1990.

39. Duckworth AR and Battershill CN: Population dynamics and chemical ecology of New Zealand Demospongiae Latrunculia sp. nov. and Polymastia croceus (Poecilosclerida: Latrunculiidae: Polymastiidae). N Z J Mar Fre Res 35: 935-949, 2001.

40. Choi HJ, Yee S-B, Park SE, Im E, Jung JH, Chung HY, Choi YH and Kim ND: Petrotetrayndiol A induces cell cycle arrest and apoptosis in SK-MEL-2 human melanoma cells through cytochrome c-mediated activation of caspases. Cancer Lett 232: 214-225, 2005.

41. Aoki S, Matsui K, Tanaka T and Kobayashi M: In situ photoaffinity labelling of the target protein for lembehyne A, a neuronal differentiation inducer. FEBS Lett 544: 223-227, 2003.

42. Aoki S, Wei H, Matsui K, Rachmat R and Kobayashi M: Pyridoacridine alkaloids inducing neuronal differentiation in a neuroblastoma cell line, from marine sponge Biemna fortis. Bioorg Med Chem 11: 1969-1973, 2003.

43. Hood KA, West LM, Northcote PT, Berridge MV and Miller JH: Induction of apoptosis by the marine sponge (Mycale) metabolites, mycalamide A and pateamine. Apoptosis 6: 207-219, 2001.

44. Domenicotti C, Marengo B, Verzola D, Garibotto G, Traverso N, Patriarca S, Maloberti G, Cottalasso D, Poli G, Passalacqua M, Melloni E, Pronzato MA and Marinari UM: Role of PKC-delta activity in glutathione-depleted neuroblastoma cells. Free Radic Biol Med 35: 504-516, 2003.

45. Ricci JE, Gottlieb RA and Green DR: Caspase-mediated loss of mitochondrial function and generation of reactive oxygen species during apoptosis. J Cell Biol 160: 65-75, 2003.

46. Prado MP, Torres YR, Berlinck RGS, Desiderá C, Sanchez MA, Craveiro MV, Hajdu E, Da Rocha RM and Machado-Santelli GM: Effects of marine organisms extracts on microtubule integrity and cell cycle progression in cultured cells. J Exp Mar Biol Ecol 313: 125-137, 2004

47. Brown JW, Kesler CT, Neary JT and Fishman LM: Effects of marine sponge extracts on mitogen-activated protein kinase (MAPK/ERK 1,2 ) activity in SW-13 human adrenal carcinoma cells. Toxicon 39: 1835-1839, 2001.

48. Sipkema D, Franssen MCR, Osinga R, Tramper J and Wijffels RH: Marine sponges as pharmacy. Mar Biotechnol 7: 142-162, 2005.

49. Yoshiji H, Kuriyama S, Ways DK, Yoshii J, Miyamoto Y, Kawata M, Ikenaka Y, Tsujinoue H, Nakatani T, Shibuya M and Fukui $\mathrm{H}$ : Protein kinase $\mathrm{C}$ lies on the signaling pathway for vascular endothelial growth factor-mediated tumor development and angiogenesis. Cancer Res 59: 4413-4418, 1999.

50. Domenicotti C, Marengo B, Nitti M, Verzola D, Garibotto G, Cottalasso D, Poli G, Melloni E, Pronzato MA and Marinari UM: A novel role of protein kinase C-delta in cell signaling triggered by glutathione depletion. Biochem Pharmacol 66: 1521-1526, 2003. 